\title{
PENGARUH USEFULNESS, EASE OF USE, RISK TERHADAP INTENTIONTO BUY ONLINEPATISSERIE MELALUI CONSUMER ATTITUDE BERBASIS MEDIA SOSIAL DI SURABAYA
}

\author{
Yudianto Oentario $^{1^{*}}$, Agung Harianto ${ }^{1}$, Jenny Irawati $^{1}$ \\ ${ }^{1}$ Program Manajemen Perhotelan, Fakultas Ekonomi, Universitas Kristen Petra, Surabaya \\ * Korespondensi; e-mail: yudianto@petra.ac.id
}

\begin{abstract}
Abstrak: Penelitian ini dilakukan untuk mengetahui apakah perceived usefulness, perceived ease of use, perceived risk berpengaruh terhadap intention to buy online patisserie melalui consumer attitude dengan media sosial instagram di masyarakat Surabaya. Penelitian ini merupakan penelitian kuantitatif. Teknik analisa yang digunakan dalam penelitian ini adalah Partial Least Square (PLS). Hasil menunjukkan bahwa perceived usefulness memiliki pengaruh positif dan signifikan terhadap consumer attitude, perceived ease of use memiliki pengaruh positif dan signifikan terhadap consumer attitude, perceived risk memiliki pengaruh negatif dan signifikan terhadap consumer attitude, dan consumer attitude memiliki pengaruh positif dan signifikan terhadap intention to buy online. Sehingga consumer attitude adalah variabel yang harus ada antara perceived usefulness, perceived ease of use, perceived risk dan intention to buy online.
\end{abstract}

Kata kunci: Perceived usefulness; perceived ease of use; perceived risk; consumer attitude; intention to buy online.

\begin{abstract}
This study was conducted to determine whether the perceived usefulness, perceived ease of use, perceived risk affect the intention to buy online patisserie through consumer attitude with instagram social media in society Surabaya. This research is quantitative. Analysis technique used in this study is Partial Least Square (PLS). Results showed that perceived usefulness has a positive and significant impact on consumer attitude, perceived ease of use has a positive and significant impact on consumer attitude, perceived risk has a negative and significant impact on consumer attitude and consumer attitude has a positive and significant impact on the intention to buy on line. So that the consumer attitude is a variable that must exist between the perceived usefulness, perceived ease of use, perceived risk and intention to buy online.
\end{abstract}

Keywords: Perceived usefulness; perceived ease of use; perceived risk; consumer attitude; intention to buy online.

\section{PENDAHULUAN}

Pada zaman modernisasi seperti saat ini, kehidupan manusia sangat bergantung pada teknologi dalam berbagai aspek kehidupannya, seperti yang disampaikan Idarosida (2015). Adanya teknologi sendiri berdampak terhadapkemajuan internet yang terus berkembang dalam beberapa tahun terakhir, yang dahulu fungsi internet hanya sebatas layanan pencari dataatau informasi dan alat komunikasi kini internet dapat dimanfaatkan sebagai media marketing, salah satunya secara online (Laohapensang, 2009). Menurut Zahay \& Roberts (2013), internet dimanfaatkan sebagai mediamarketing yang menjual dan mempromosikan produk melalui media elektronik. Salah satu media elektronik berupa media sosial yang dapat mendukung penjualan online shopping channels.

Munculnya peluang bisnis online shopping di Surabaya dimanfaatkan pengusaha untuk membuka bisnis, yaitu; industri kuliner dibidang patisserie secara online sebagaibentukpemanfaatan media sosial yang tersedia. Adanya patisserie online juga disambut secara positif oleh masyarakat umum dikarenakan konsumen memilki gaya hidup yang ingin serba praktis ditambah mobilitas yang tinggi, secara tidak langsung dapat mempengaruhi konsumen untuk lebih berminat terhadap patisserie online dalam memenuhi kebutuhan dibanding ke toko tradisional ditengah rutinitas yang padat (Audia, 2014).

Hal ini didukung hasil penelitian pendahuluan yang dilakukan penulis. Menunjukkan adanya minat beli produk pastisserie sebanyak 5 dari 10 orang melalui online shop dan media instagram terpecaya sebagai salah satu media sosial andalan responden. Menurut responden, dengan menggunakan media sosial instagram, responden merasa dimudahkan karena dapat diakses dari mana dan kapan saja, bisa juga membandingkan merek, harga, sehingga tidak ribet. Akan tetapi, tidak semua responden merasakan kelebihan tersebut, ada kalanya pihak online shop menyertakan berbagai aturan ditambah responden khawatir akan kemungkinan risiko yang timbul, hal ini dapat membuat responden tidak merasa nyaman dan berminat untuk berbelanja di online shop.

Sebab adanya peluang bisnis didukung minat beli online konsumen menjadi fenomena di masyarakat Surabaya, beberapa variabel akan dijelaskan dalam penelitian ini berdasar pada teori Technology Acceptance Model (TAM) sebagai pendukung 
fenomena yang terjadi, antara lain; (1) Kegunaan (perceived usefulness) dari media online shop tentang manfaat, efektifitas dan produktifitas produk sesuai kebutuhan. (2) Kemudahan (perceivedease of use), media dikatakan mudah jika itu mudah dipahami, dioperasikan dan fleksibel untuk diakses. (3)Risiko (perceivedrisk) berbelanja secara online dibandingkan dengan toko tradisional, yang dianggap menjadi penghalang, karena risiko yang ada dapat menjadi alasan konsumen untuk tidak berminat melakukan pembelian online (Haryo \& Haryanto, 2015). Beberapa variabel ini secara tidak langsung mempengaruhi minat konsumen terhadap instagram sebagai media perantara untuk berbelanja di online shop. Pernyataan ini sejalan seperti yang diungkapkan Schiffman \& Kanuk (2007) (dalam Rendra, 2011), bahwa seluruh kegiatan pemasaran yang berhubungan dapat mempengaruhi sikap konsumen (consumer attitude).

Berdasarkan fenomena yang pro dan kontra serta mengacu pada teori yang telah dikemukakan diatas, maka penelitian ini dilakukan dengan maksud untuk menganalisa intention to buy online produk patisserie dimasyarakat Surabaya yang diakibatkan consumer attitude sebagai dampak sikap konsumen yang dipengaruhi oleh variabel perceivedusefulness, perceivedease of use, dan perceived risk bisnis online di media sosial Instagram.

\section{TEORI PENUNJANG}

\section{Internet Marketing}

El-Gohary (2010) mengemukakan, internet marketing sendiri adalah sebuah filosofi baru dan praktek bisnis moderen yang melibatkan pemasaran barang, jasa, informasi dan ide melalui media internet.

Keuntungan utama internet marketing adalah mengurangi biaya dan meningkatkan jangkauan. Biaya internet marketing lebih rendah dibandingkan toko tradisional seperti face-to-face atau perantara penjual/distributor. Selain itu, internet marketing memungkinkan pemasar untuk menjangkau pelanggan yang tidak dapat diakses karena keterbatasan waktu dan lokasi (Jagdish \& Sharma, 2005). Sedangkan menurut Onno \& Aang (2001), kelemahan utama internet marketing adalah:

1. Barang tidak dapat langsung digunakan, harus menunggu pengiriman.

2. Barang atau jasa tidak dapat dicoba secara langsung.

3. Kondisi barang atau jasa, ataupun kualitas sesungguhnya tidak dapat didapatkan secara maksimal karena barang atau jasa yang sebenarnya tidak didepan mata, tidak dapat disentuh, ataupun dicoba.

\section{Technology Acceptance Model (TAM)}

Sebab internet marketing menggunakan teknologi, penelitian ini menggunakan Technology Acceptance Model (TAM) untuk memprediksi perilaku konsumen dalam pengambilan keputusan pembelian belanja online, sebab TAM merupakan salah satu teori yang paling umum digunakan untuk menjelaskan perilaku belanja online (Davis, 1989).

TAM yang dikembangkan oleh Davis (1989) diadopsi berdasarkan Theory of Reasoned Action (TRA) oleh Ajzen \& Fisben (1975), merupakan teori tentang tindakan dan persepsi individu terhadap suatu hal guna menentukan sikap dan minat berperilaku. Menggunakan media online sendiri bergantung pada dua variabel utama yang disebut persepsi kegunaan (perceived usefulness), dan persepsi kemudahan (perceived ease of use).Namun seiring berjalannya waktu ditambahkan persepsi risiko (perceived risk) oleh Pavlou (2003) (dalam Han, et. al., 2007).

\section{Persepsi Kegunaan Penggunaan (Perceived- usefulness)}

Jogiyanto (2008) mengemukakan, definisi persepsi kegunaan sebagai sejauh mana individu yakin dengan menggunakan suatu teknologi akan meningkatkan kinerja pekerjaannya. Jika individu beranggapan dengan media informasi berguna maka dia akan menggunakannya. Sebaliknya jika individu beranggapan dengan media informasi kurang berguna maka dia tidak akan menggunakannya.

Davis \& Venkatesh (2000) mengemukakan, persepsi kegunaan dapat diukur dengan menggunakan indikator sebagai berikut: useful, beneficial, effectiveness, dan productivity.

\section{Persepsi Kemudahan Penggunaan (Perceived ease of Use)}

Jogiyanto (2008) mengemukakan, definisi persepsi kemudahan sebagai sejauh mana individu yakin dengan menggunakan teknologi akan bebas dari usaha. Jika individu menganggap media informasi mudah digunakan maka dia akan menggunakannya. Sebaliknya jika individu menganggap media informasi tidak mudah digunakan maka dia tidak akan menggunakannya.

Davis \& Venkatesh (2000) mengemukakan, persepsi kemudahan dapat diukur dengan indikator sebagai berikut: clear and understandable, less effort, dan easy to use. 


\section{Persepsi Risiko (Perceived Risk)}

Bhatnagar, et al. (2000) mengemukakan, internet dianggap sebagai media belanja berisiko. Sebagian besar konsumen berpikir bahwa risiko dalam belanja online lebih besar dari manfaatnya dalam pembelian. Kim, et al. (2007) (dalam Kusdani, 2014) juga mengemukakan, konsumen merasa cemas tentang risiko yang mungkin terkait dengan berbelanja melalui internet. Persepsi risiko dapat didefinisikan sebagai prediksi konsumen tentang potensi ketidakpastian dari transaksi online.

Ye (2004) menyatakan, risiko yang ada diukur dengan menggunakan indikator sebagai berikut: fraud risk, delivery risk, financial risk, process and time risk, product risk, privacy risk, dan information risk.

\section{Sikap Konsumen (Consumer Attitude)}

Schiffman \& Kanuk (2007) (dalam Rendra, 2011) menyatakan, semua kegiatan pemasaran yang berhubungan dapat mempengaruhi sikap konsumen. Sikap didefnisikan sebagai perasaan batin individu yang menunjukkan apakah dia suka atau tidak suka sesuatu (misalnya; merek atau layanan). Sikap juga mendorong kecenderungan untuk bertindak dengan cara yang baik atau buruk, objeknya dapat dikategorikan sebagai sikap, orang, produk, layanan, organisasi, ide, masalah, dan juga internet.

Consumer Attitude menurutSimamora (2002) (dalam Imancezar, 2011) dapat diukur dengan indikators sebagai berikut:Cognitivecomponent (perseptual), affective component (emosional), dan behavioral component (perilaku).

\section{Minat Beli Online (Intention to Buy Online)}

Minat beli ini ditunjukkan melalui adanya sikap positif dan perasaan senang terhadap suatu produk yang akan diikuti dengan tindakan lebih lanjut untuk membeli. Simamora (2002) (dalam Imancezar, 2011) mengemukakan, minat adalah sesuatu yang pribadi dan berhubungan dengan sikap. Individu yang berminat terhadap suatu objek akan memiliki dorongan untuk melakukan serangkaian perilaku untuk mendekati atau mendapatkan objek tersebut.

Intention to Buy Online menurut Ferdinand (2007) (dalam Ferista, 2014) diukur dengan indikator sebagai berikut: Minat transaksional, refrensial, eksploratif, dan preferensial.

Kerangka konseptual yang digunakan dalam penelitian ini, sejalan dengan replikasi jurnal dari Haryo \& Haryanto, 2015.Dimana intention to buy online terhadap produk patisserie di masyarakat Surabaya ini diakibatkan oleh consumer attitude sebagai dampaksikap konsumen yang dipengaruhi oleh variabel usefulness, ease of use, dan risk pada bisnis online di media sosial instagram.

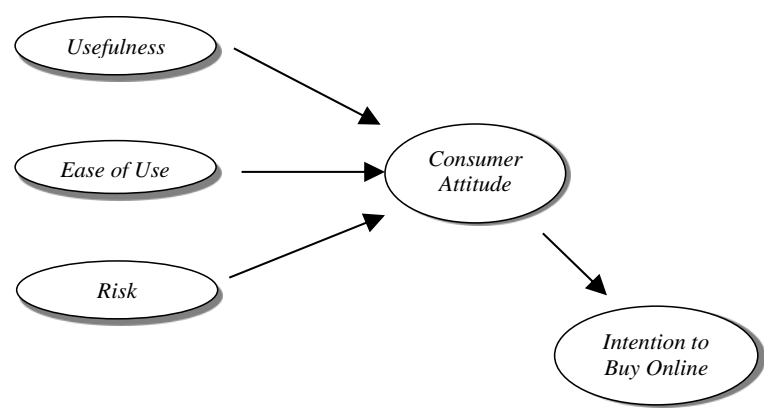

Gambar 1. Framework

\section{METODE PENELITIAN}

Pendekatan kuantitatif eksploratori digunakan untuk mencapai tujuan penelitian. Menggunakan nonprobability sampling dengan teknik convenience sampling, karena populasi tidak diketahui dengan pasti atau dapat diberi nomor identifikasi jumlah masyarakat Surabaya pengguna media yang pernah berbelanja produk patisserie secara online, populasi ini disebut populasi infinit.

Metode pengumpulan data yang dilakukan dalam penelitian ini menggunakan kuisioner dengan skala likert dalam lima angka penilaian kepada 100 sampel. Kuesioner ini disebar $70 \%$ secara online melalui google form dan juga30\%secara offline. Pada penelitian ini, variabel dikelompokkan menjadi:

1. Independent variable (variabel bebas/eksogen), yaitu; $\left(\mathrm{X}_{1}\right)$ Perceived Usefulness, $\left(\mathrm{X}_{2}\right)$ Perceived Ease of use, dan $\left(\mathrm{X}_{3}\right)$ Perceived Risk.

2. Dependent variable (variabel terikat/endogen), yaitu; $\left(\mathrm{Y}_{1}\right)$ Intention to Buy Online.

3. Intervening variable (variabel mediasi) $\left(\mathrm{Y}_{2}\right)$ Consumer Attitude.

Teknik analisa data yang digunakan adalah Structural Equation Modelling (SEM) dengan pendekatan Partial Least Square (PLS) 3.2.4.

\section{Goodness of Fit Outer Model}

\section{Uji Validitas}

Pada uji validitas ini dapat dilihat untuk indikator PR_5 dan PR_6 tidak valid karena nilai $<0.50$. Pengujian convergent validity dilihat dari outer loading dimana nilainya telah $>0.50$ dan juga discriminant validity yang dilihat dari crossloading (juga tertinggi dibanding yang lain) dengan artian tidak ada multikorelasi variabel. Demikian dapat dinyatakan variabel yang valid dapat digunakan untuk penelitian lebih lanjut. 


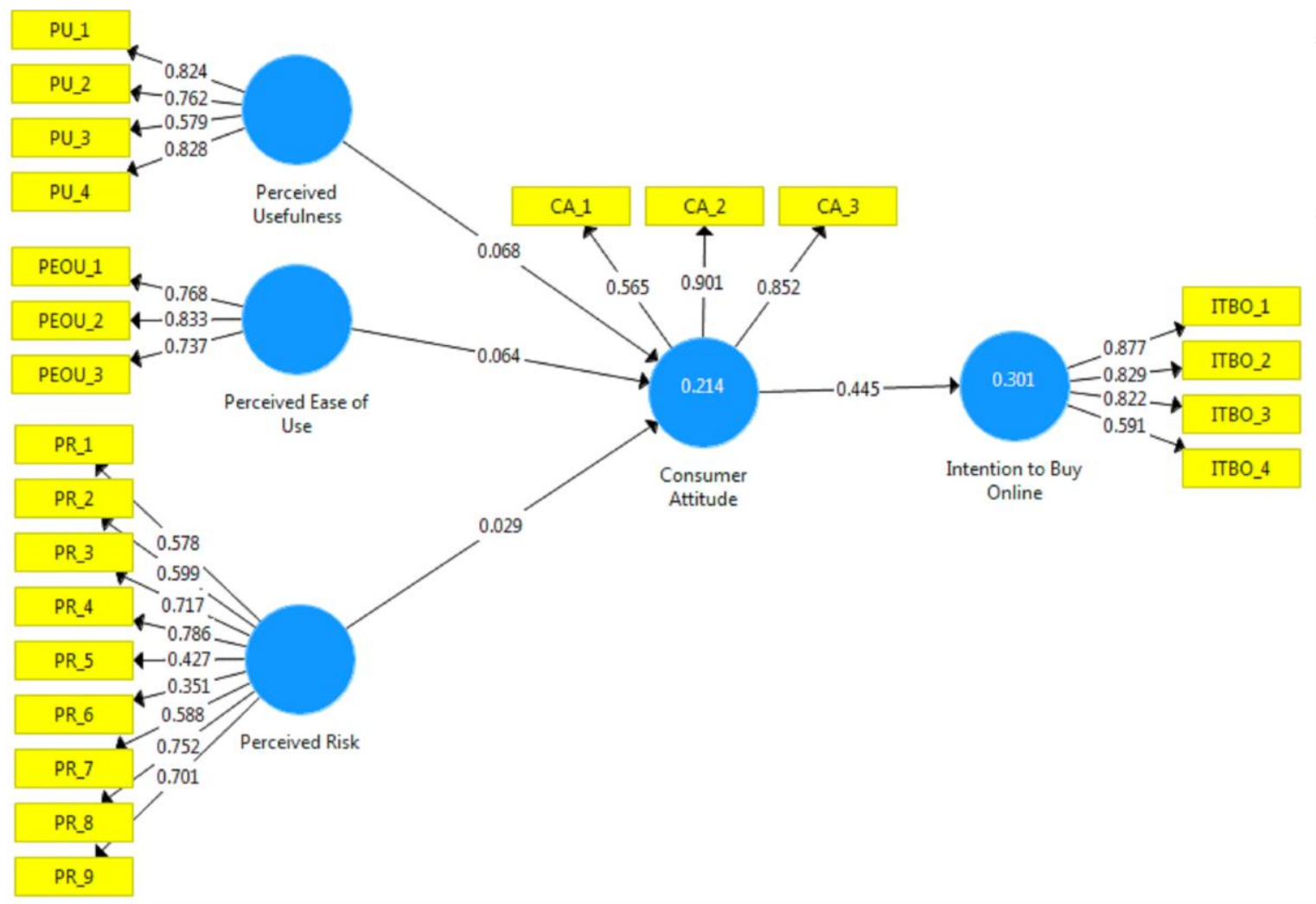

Gambar 2. Structural Model PLS before rectification

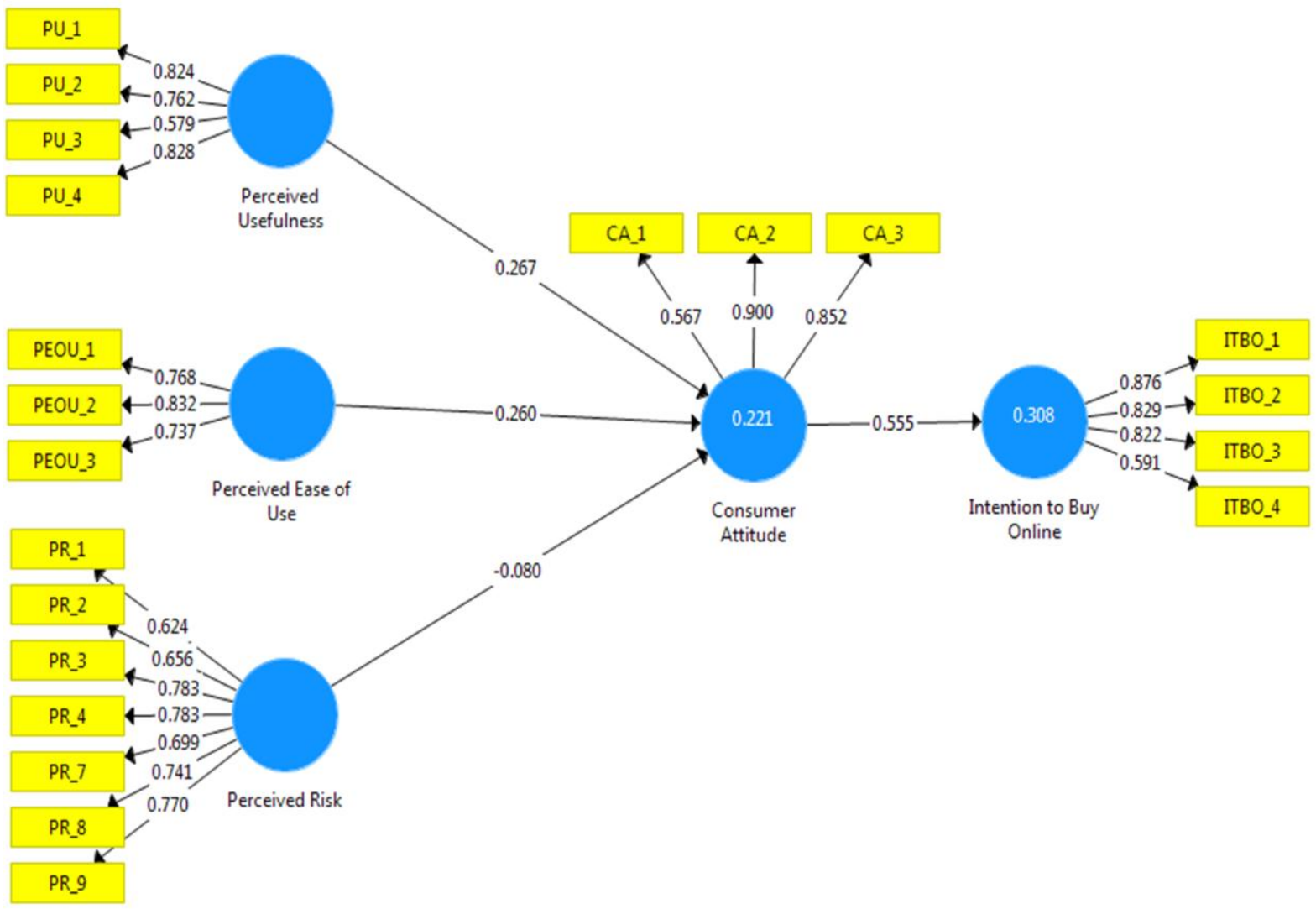

Gambar 3. Structural Model PLS after rectification 
Berdasarkan Gambar 2 diketahui, pada model sebelum pembetulan indikator PR_5 dan PR_6 tidak valid maka tidak digunakan dalam penelitian ini. Kemudian dilakukan pembetulan dan hasil seluruh indikator diatas valid karena nilainya diatas 0.50 .

\section{Uji Reliabilitas}

Tahap selanjutnya adalah uji reliabilitas, pengujian melalui composite reliability dimana nilainya telah $>0.70$ kemudian juga cronbachs alpha yang merupakan nilai terrendah reliabilitas dimana nilai $>0.60$. Dengan demikian, dapat dinyatakan reliabel dan dapat digunakan untuk penelitian lebih lanjut.

\section{Goodness of Fit Inner Model}

Nilai $R$-Square dimana variabel consumer attitude yang dipengaruhi oleh variabel perceived usefulness, ease of use, dan risk adalah sebesar $22,14 \%$. Sedangkan intention to buy online yang dipengaruhi variabel perceived usefulness, ease of use, dan risk adalah sebesar 30.78\%. Goodness of fit penelitian ini adalah $\mathrm{Q}^{2}=46.1 \%$ yang dapat diartikan $53.9 \%$ dipengaruhi variabel lainnya.

\section{PEMBAHASAN}

Hasil perhitungan inner weight pada pengaruh perceived usefulness terhadap consumer attitude menunjukkan nilai $\mathrm{T}$ hitung sebesar 3.339 dimana lebih besar dari pada 1,96. Hal tersebut menunjukkan bahwa perceived usefulness mempunyai pengaruh yang positif dan signifikan terhadap consumer attitude, dengan demikian Hipotesis 1 diterima. Adanya pengaruh positif ini, menunjukkan bahwa responden akan memilki consumer attitude yang semakin baik jika didukung dengan media sosial yang bermanfaat dan berguna dalam memenuhi kebutuhan responden. Pernyataan ini sejalan dengan yang diungkapkan oleh; Rodgers \& Thorson (2000), Jee \& Lee (2002), Steinfield, (2002) (dalam Kusdani, 2015).

Kemudian untuk hasil perhitungan inner weight pada pengaruh perceived ease of use terhadap consumer attitude menunjukkan nilai $\mathrm{T}$ hitung sebesar 2.862 dimana lebih besar dari pada 1,96. Hal tersebut menunjukkan bahwa perceived ease of use mempunyai pengaruh yang positif dan signifikan terhadap consumer attitude, dengan demikian Hipotesis 2 diterima. Penelitian ini sejalan dengan yang diungkapkan oleh Ramayah \& Ignatius (2010), dengan adanya pengaruh positif, menunjukkan responden akan memilki consumer attitude yang semakin baik jika didukung dengan media sosial yang memudahkan responden dalam memenuhi kebutuhannya.
Kemudian untuk hasil perhitungan inner weight pada pengaruh perceived risk terhadap consumer attitude menunjukkan nilai $\mathrm{T}$ hitung sebesar 0.477 dimana lebih kecil dari pada 1,96. Hal tersebut menunjukkan seharusnya perceived risk mempunyai pengaruh yang negatif namun tidak signifikan terhadap consumer attitude, dimana Hipotesis 3 seharusnya tidak diterima.Namun, khusus untuk variabel ini pengertiannya berbeda, hal ini disebabkan pengertian responden tentang tidak merasakan adanya risiko terhadap media belanja online dalam memenuhi kebutuhannya justru berarti sebaliknya.Responden merasakan adanya risiko yang tinggi terhadap media belanja online, sejalan dengan analisa deskriptif yang telah dilakukan dan yang telah diungkapkan oleh Forsythe (2006).

Begitu juga hasil perhitungan inner weight pada pengaruh consumer attitude terhadap intention to buy online menunjukkan nilai $\mathrm{T}$ hitung sebesar 8.176 dimana lebih besar dari pada 1,96. Hal tersebut menunjukkan bahwa consumer attitude mempunyai pengaruh yang positif dan signifikan terhadap iontention to buy online, dengan demikian Hipotesis 4 diterima. Adanya pengaruh positif ini, menunjukkan bahwa responden akan memilki intention to buy online yang semakin tinggi jika didukung dengan consumer attitude dari responden dalam memenuhi kebutuhannya. Penelitian ini sejalan dengan yang diungkapkan oleh; Mowen \& Minor (2002) (dalam Kusdani, 2014) dan Suprapti (2010) (dalam Novita \& Giantari, 2016).

Sehingga dari hasil penelitan dan pembagian kuisioner dapat ditemukan hasil yang dapat menerima Hipotesis 5 dimana consumer attitude berfungsi sebagai variabel mediasi antara perceived usefulness, perceived ease of use, perceived risk dengan intention to buy online. Consumer attitude adalah variabel yang harus ada untuk memberikan pengaruh dari perceived usefulness, perceived ease of use, perceived risk ke intention to buy online. Penelitian ini sejalan dengan yang diungkapkan oleh; Schiffman \& Kanuk (2007) (dalam Rendra, 2011), yaitu: sikap didefinisikan sebagai perasaan yang menunjukkan apakah individu suka atau tidak suka akan suatu hal, yang mendorong kecenderungan untuk bertindak dengan cara yang baik atau buruk.

\section{KESIMPULAN DAN SARAN}

\section{Kesimpulan}

Penelitian ini memilki goodness of fit hanya sebesar $46.1 \%$. Dimana intention to buy online yang dipengaruhi oleh consumer attitude sebagai dampak 
dari perceived usefulness, perceived ease of use, dan perceived risk hanyalah sebesar itu. Dapat diartikan terdapat variabel-variabel lain yang dapat mempengaruhi consumer attitude dan intention to buy online, yang telah dijelaskan sebelumnya.

\section{Saran}

Beberapa saran yang nantinya dapat berguna bagi pihak-pihak yang berkepentingan untuk penelitian selanjutnya, yaitu:

1. Bagi penelitian selanjutnya, disarankan menggunakan metode sampling yang lain seperti; quota sampling. Dalam penelitian ini menggunakan convenience sampling, sehingga range usia yang didapat tidak merata. Harapannya untuk kedepannya usia responden $\geq 25$ tahun lebih diperbanyak supaya nantinya hasil yang ada benar-benar representatif dan data yang dikumpulkan lebih terpecaya.

2. Bagi pemilik usaha senantiasa meningkatkan pelayanan dari segi kualitas, informasi, dan keamaanan agar segala kecemasan yang dikhawatirkan konsumen tidak menjadi hambatan dalam keinginan untuk berbelanja online.

\section{DAFTAR PUSTAKA}

Audia, S. (2014). Perilaku konsumtif akibat pengaruh hedonisme di kalangan mahasiswa jurusan geografi Universitas Negeri Malang. https://www. academia.edu/8667228/JURNAL_pengaruh_he donisme.

Bhatnagar, A., Misra, S. \& Rao, H.R.(2000).On risk, convenience and internet shopping behavior. Communications of the ACM, 48(2), 98-105.

Davis, F.D. (1989). Perceived usefulness, perceived ease of use and user acceptance of information technology.MIS quarterly, 13(3), 319-340.

Davis, F.D. \& Venkatesh, V. (2000).A theoritical extension of the technology acceptance model four longitudinal field studies.Management science: 46(2), 186-204.

El-Gohary, H. (2010).E-Marketing - A literature review from a small businesses perspective. International journal of business and social science, (1), 214-244.

Ferista, Y. (2014). Pengaruh risiko yang di persepsikan dan kepuasan konsumen terhadap minat beli pada konsumen kaskus website di Universitas Negeri Yogyakarta. (TA No. 15009/FE/2014). Unpublished undergraduate thesis, Universitas Negeri Yogyakarta, Yogyakarta.
Forsythe, S., Liu, C., Shannon, D. \& Gardner, L.C. (2006).Development of a scale to measure the perceived benefits and risks of online shopping. Journal of interactive marketing, 20(2), 55-75.

Han, H. J., Kim, Y. B. \& Im, I. (2007). The effects of perceived risk and technology type on users' acceptance of technologies. Information \& Management, 45(2008), 1-9.

Haryo, B.P. \& Haryanto, B. (2015). Factors affecting purchase intention of online shopping in Zalora Indonesia. British journal of economics, management \& trade, 9(1), 1-12.

Idarosida. (2015, October 21). Perkembangan dan kemajuan teknologi.http://idarosida07.blogspot. co.id/2015/10/perkembangan-dan-kemajuanteknologi.html.

Imancezar, R. G. (2011). Analisis pengaruh motivasi konsumen, persepsi konsumen, dan sikap konsumen terhadap keputusan pembelian. (TA No. 28956/FE/2011). Unpublished undergraduate thesis, Universitas Diponegoro, Semarang.

Jagdish, N.S. \& Sharma, A. (2005). International Emarketing: Opportunities and issues, 22(6), 611 622.

Jogiyanto. (2008). Sistem informasi keperilakuan ed. rev. Yogyakarta: Andi.

Kusdani, D. (2014). Persepsi terhadap sikap dan minat pengguna layanan internet pada perusahaan jasa asuransi. Jurnal organisasi dan manajemen, 10(2), 97-112.

Laohapensang, O. (2009). Factors influencing internet shopping behaviour: "A survey of consumers in Thailand". Journal of fashion marketing and management: An international journal, 13(4), 501.

Novita, S.L. \& Giantari, A.K. (2016). Peran sikap dalam memediasi pengaruh perceived usefulness terhadap niat menggunakan internet di Kota Denpasar. E-Jurnal manajemen unud, 5(3), 1513-1541.

Onno, W.P. \& Aang, A.W. (2001).Mengenal ecommerce. Jakarta: PT Elex Media Komputindo.

Ramayah, T. \& Ignatius, J. (2010). Intention to shop online: The mediating role of perceived ease of use. Middle - East journal of scientific research, 5(3), 152-156.

Rendra. (2011). Perbedaan perceived risk online shoppers dan non-online shoppers pada jual beli online. Unpublished undergradute thesis, Universitas Indonesia, Depok.

Ye, N.Y. (2004). Dimension of consumer's perceived risk in online shopping. Electronic, science and technology of China, 2(3), 175-182.

Zahay \& Roberts. (2013). Internet marketing: Integration online \& offline strategies. SouthWestern. 